\title{
Comparison of the Voltammetric Behavior of Metronidazole at a DNA-Modified Glassy Carbon Electrode, a Mercury Thin Film Electrode and a Glassy Carbon Electrode
}

\author{
Ana Maria Oliveira Brett, ${ }^{+*}$ Silvia H.P. Serrano, ${ }^{++}$Ivano G.R. Gutz, ${ }^{++}$and Mauro A. La-Scalea ${ }^{+,++}$ \\ + Departamento de Química, Universidade de Coimbra, 3000 Coimbra, Portugal \\ ${ }^{++}$Instituto de Química, Universidade de São Paulo, C.P. 26077, 05599-970 São Paulo, Brazil
}

Received: May 22, 1996

Final version: August 12, 1996

\begin{abstract}
The electroanalytical performance at three electrodes: DNA-modified glassy carbon electrode, mercury thin film electrode and glassy carbon electrode, for the study of the electrochemical reduction of metronidazole is compared. All three electrodes showed a similar trend in the reduction mechanism for metronidazole, dependent on $\mathrm{pH}$ in the acid and neutral region and independent in alkaline media, although there was a shift in the peak potentials to more negative values when a bare glassy carbon electrode was used compared to the other two. Besides the advantage of using a solid electrode for the reduction of metronidazole, the DNA-modified glassy carbon electrode enables a lower detection limit of $1.0 \mu \mathrm{M}$ owing to the preconcentration of the drug on the electrode surface, which is not the case for the mercury thin film or bare glassy carbon electrodes.
\end{abstract}

Keywords: DNA, Metronidazole, Modified electrodes, Nucleic acids, Biosensors

\section{Introduction}

Metronidazole (2-methyl-5-nitroimidazole-1-ethanol) belongs to a group of nitroimidazole drugs used in therapeutics [1]. Nitroimidazole derivatives are selectively toxic to anaerobic bacteria and protozoarium. The reduction of nitroimidazoles follows a complex mechanism and theoretically the nitro group can receive as many as six electrons to form the corresponding amine [2] (Scheme 1).

The mechanism of the biological action of nitroimidazoles depends on the reduction of the nitro group which leads to intermediate species which interact with DNA, oxidizing it and liberating thymidine phosphate, causing a lesion characterized by destabilization and damage of the double helix $[1,2]$.

Electrochemical techniques have been applied to the study of the mechanism of action of the nitroimidazoles as antimicrobial agents [3], and in pharmaceutical [4] and clinical [5] analysis. DC polarographic studies [6] showed that the half-wave potential of metronidazole changes in the presence of DNA bases such as adenine, guanine and cytosine, to a lesser extent. These bases interact easily with the hydroxylamine intermediate generated during reduction of metronidazole. Voltammetric studies [6-8] have shown two reduction waves in acid media for nitroimidazole derivatives, the first wave corresponding to the reduction of the nitro group to form the intermediate hydroxylamine (-NHOH), transferring four electrons and the second wave corresponding to hydroxylamine reduction to amine $\left(-\mathrm{NH}_{2}\right)$, transferring two electrons. Similar results were obtained for ornidazole [9], but on increasing the $\mathrm{pH}$ the second cathodic wave disappeared.

Some compounds show only one reduction wave in basic media corresponding to the transfer of six electrons. The voltammetric behavior of metronidazole at a mercury drop electrode and $\mathrm{pH} 7.3$ was the same as that observed in acid media with the half-wave potentials of the two waves being respectively $-0.34 \mathrm{~V}$ and $-0.92 \mathrm{~V}$ (vs. SCE) [6].
On the other hand, Leach et al. [12] observed only one cathodic wave for the reduction of nitroimidazole and obtained a half-wave potential of $-0.465 \mathrm{~V}$ for metronidazole in a neutral buffer supporting electrolyte solution, quite different from the results of $[6,7]$.

Recently Zuman and co-workers $[10,13,14]$ found that the halfwave potentials for the first reduction step of the nitro group are shifted to more negative potentials with increasing pH. Such a change in the values of $E_{1 / 2}$ occurs both in aqueous media, where the first reduction wave always corresponds to a four-electron transfer, and in solutions with different percentages of organic solvent. These shifts are attributed to an acid-base preequilibrium followed by the first electron transfer to form the nitro radical.

In this article the results obtained for the electrochemical reduction of metronidazole using three different electrode materials are presented and compared: DNA-modified glassy carbon electrode (DNA-GCE), mercury thin film electrode on a glassy carbon substrate (MTFE) and glassy carbon electrode (GCE). The results from this comparative study will enable us to study the interaction of metronidazole with DNA and to quantify this interaction using the DNA-modified GCE.

\section{Experimental}

Metronidazole (MTZ) was supplied by Rhodia Laboratories. Calf thymus DNA (sodium salt, type I), was obtained from Sigma Chemical Co. and was used without further purification. Citric acid/ phosphate buffer solutions with $\mathrm{KNO}_{3}$ of ionic strength 0.2 were used in all experiments at $\mathrm{pH} 4.5$ and 7.4 , and were prepared using analytical grade reagents and purified water from a Millipore MilliQ system.

The DNA-modified working electrode was glassy carbon modified with adsorbed DNA, the counter electrode was a $\mathrm{Pt}$<smiles>Cc1ncc(N(CC(C)C)C(=O)O)n1CCO</smiles>

Scheme 1 . 
wire, and the reference electrode was a SCE, all contained in a onecompartment cell. The DNA-GCE was prepared by covering a glassy carbon electrode (Tokai, GC20, area $0.07 \mathrm{~cm}^{2}$ ) with $3 \mathrm{mg}$ of DNA dissolved in $80 \mu \mathrm{L}$ of $\mathrm{pH} 4.5$ acetate buffer and leaving the electrode to dry. After drying, the electrode was immersed in acetate buffer solution and a constant potential of $+1.4 \mathrm{~V}$ applied during $5 \mathrm{~min}$. Then it was transferred to a solution containing single stranded DNA and differential pulse voltammograms were recorded in the range 0 to $+1.4 \mathrm{~V}$ until stabilization of the peak currents that correspond to adenine and guanine electrooxidation occurred.

The mercury thin film electrode was prepared by immersing the glassy carbon electrode in a solution of $10^{-2} \mathrm{M} \mathrm{Hg}\left(\mathrm{NO}_{3}\right)_{2}$ and electrolyzing it at $-1.0 \mathrm{~V}$ during $60 \mathrm{~s}$. Afterwards the electrode was transferred to the solution containing metronidazole.

The voltammograms were recorded using a $\mu$ Autolab potentiostat/galvanostat running with GPES version 3 software, from EcoChemie, Utrecht, Netherlands. The differential pulse voltammetry conditions were: pulse amplitude $50 \mathrm{mV}$, pulse width $70 \mathrm{~ms}$ and scan rate $5 \mathrm{mV} \mathrm{s}^{-1}$.

\section{Results and Discussion}

Up until now, all studies on the electrochemical reduction of metronidazole $[6-8,10]$ have been done using the mercury drop electrode. The DNA-modified glassy carbon electrode has recently been developed in our group [15] for the study of the interaction of DNA with carboplatin and its quantification in serum samples from patients undergoing treatment with this drug. It was expected that this electrode would respond also to metronidazole because of interaction with and damage to DNA by the metronidazole reduction products.

Differential pulse voltammograms at $\mathrm{pH} 4.5$ and 7.4 for the reduction of metronidazole, for a concentration of $54.3 \mu \mathrm{M}$, using the three different electrode materials: DNA-modified glassy carbon electrode (DNA-GCE), mercury thin film electrode (MTFE) and glassy carbon electrode (GCE), are shown in

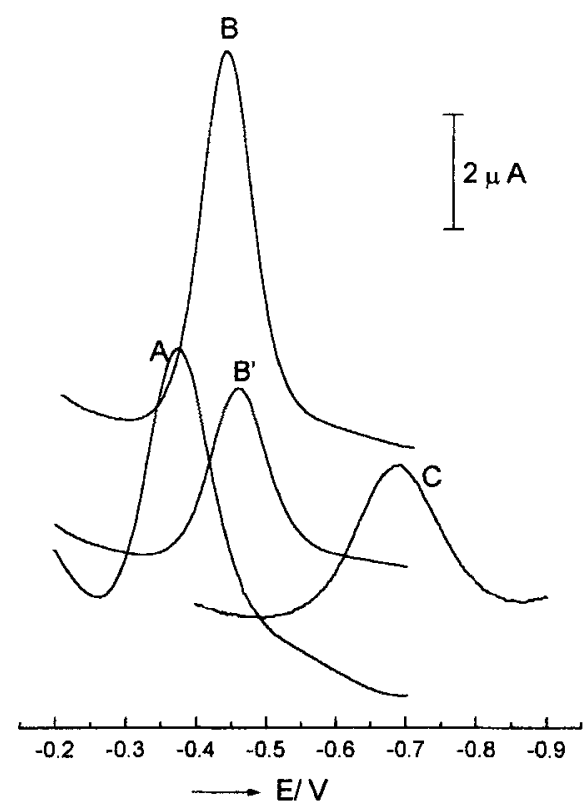

Fig. 1. Differential pulse (DP) voltammograms of $54.3 \mu \mathrm{M}$ metronidazole in pH 4.5 citrate/phosphate buffer: A) MTFE; B) DNA-GCE with 2 min preconcentration; $B^{\prime}$ ) DNA-GCE; C) bare GCE. DP conditions: pulse amplitude $50 \mathrm{mV}$, pulse width $70 \mathrm{~ms}$, pulse interval $0.4 \mathrm{~s}$ and scan rate $5 \mathrm{mV} \mathrm{s}^{-1}$.
Figures 1 and 2, respectively. The values for the peak potentials are in Table 1. This peak corresponds to the reduction of the nitro group to form the hydroxylamine. In fact, the peak half-width using the DNA-GCE or MTFE is $\approx 100 \mathrm{mV}$ whereas using a bare GCE is $\approx 190 \mathrm{mV}$; the difference in peak potentials is $100 \mathrm{mV}$. At pH 4.5 a very small peak at a potential of $-0.85 \mathrm{~V}$ can be observed corresponding to subsequent reduction of the hydroxylamine; no

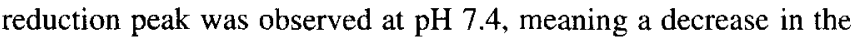
rate of protonation of hydroxylamine with increasing $\mathrm{pH}$.

Figure 3 shows a plot of $E_{\mathrm{p}}$ vs. $\mathrm{pH}$ for the reduction of metronidazole using the three different electrode materials: DNAGCE, MTFE and GCE. The lines correspond to $59 \mathrm{mV}$ per $\mathrm{pH}$ unit with the DNA-GCE and the GCE, and $90 \mathrm{mV}$ per $\mathrm{pH}$ unit with the MTFE. This confirms that the reduction mechanism using the DNA-GCE is pH dependent in acid and neutral media although for $\mathrm{pH}$ values higher than 8 the reduction is $\mathrm{pH}$ independent, in agreement with previous data using a mercury electrode $[11,12]$. It is assumed that in acidic media at DNA-GCE and GCE the complete reduction of metronidazole to the corresponding hydroxylamine involves 4 electrons and 4 protons followed by a two electron reduction of the hydroxylamine, and that in alkaline solution metronidazole is reduced in one six-electron step. However, it is easier to reduce the metronidazole using the DNAGCE since the peak potentials are ca. $100 \mathrm{mV}$ more positive than when using the bare GCE.

The DNA-modified glassy carbon electrode enabled preconcen tration of metronidazole, which is not possible with the bare GCE or with the MTFE, and permits the quantification of lower concentrations than those obtained when using an unmodified glassy carbon electrode. The possibility of accumulating target species onto a DNA-modified hanging mercury drop electrode has already been exploited in order to determine submicrogram quantities of supercoiled, linear and denatured DNA in a procedure called adsorptive transfer stripping voltammetry [14, 15].

In fact, the response for metronidazole is much better using a DNA-GCE with preconcentration: the peak current is doubled and

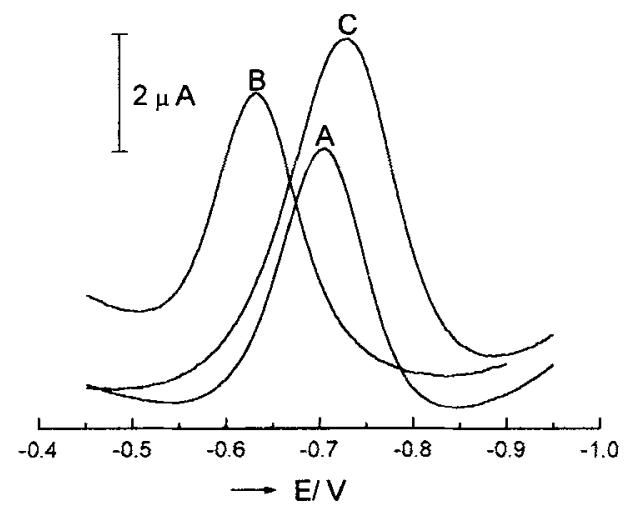

Fig. 2. Differential pulse (DP) voltammograms of $54.3 \mu \mathrm{M}$ metronidazole in pH 7.4 citric acid/phosphate buffer: A) MTFE; B) DNA-GCE; C) bare GCE. DP conditions: pulse amplitude $50 \mathrm{mV}$, pulse width $70 \mathrm{~ms}$, pulse interval $0.4 \mathrm{~s}$ and scan rate $5 \mathrm{mV} \mathrm{s}^{-1}$.

Table 1. Values for the peak potentials [V] at the three different electrodes.

\begin{tabular}{|c|c|c|}
\hline $\begin{array}{l}\text { Electrode } \\
\text { material }\end{array}$ & $p H 4.5$ & $p H 7.4$ \\
\hline $\begin{array}{l}\text { GCE } \\
\text { DNA-GCE } \\
\text { MTFE }\end{array}$ & $\begin{array}{l}-0.692 \\
-0.472 \\
-0.398\end{array}$ & $\begin{array}{l}-0.732 \\
-0.632 \\
-0.706\end{array}$ \\
\hline
\end{tabular}




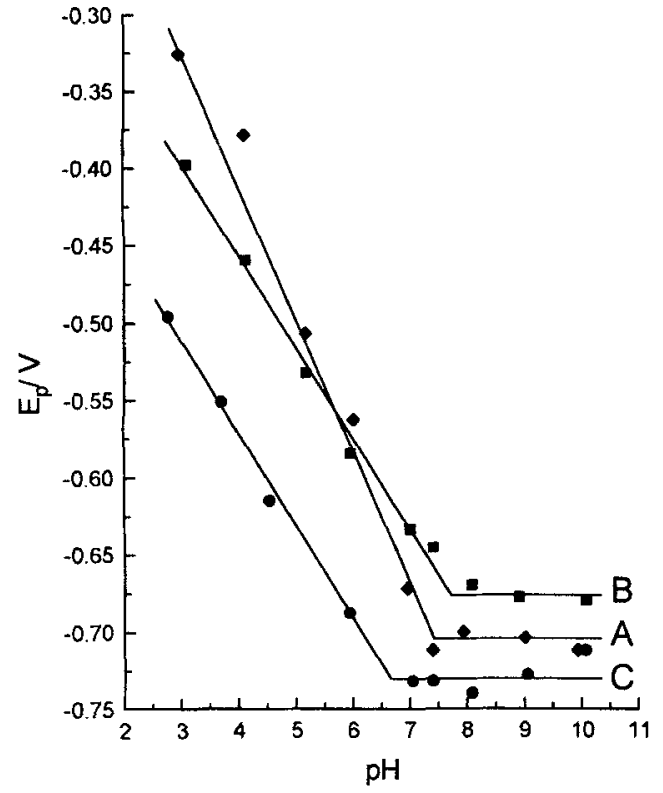

Fig. 3. Plot of $E_{\mathrm{p}}$ vs. pH for a $5.4 \times 10^{-5} \mathrm{M}$ MTZ solution: B) 1 : DNA-GCE with preconcentration during 2 min at $0.0 \mathrm{~V}$ with stirring; C) $\quad$ : Bare GCE; A) $\bullet$ : MTFE. its width is smaller than with bare GCE or the MTFE. However, preconcentration can cause problems of accumulation and memory effects on the electrode surface and it may be necessary to clean the electrode in buffer solution after each deposition when using the DNA-GCE for successive depositions.

In Table 2 are shown, for comparison, the calibration plot data at $\mathrm{pH} 4.5$ and 7.4 for the three electrode materials: DNA-GCE, MTFE and GCE. Effectively, at $\mathrm{pH} 4.5$ without preconcentration there is no apreciable benefit from the use of the DNA-GCE. However, the calibration plots for the DNA-GCE even without preconcentration at $\mathrm{pH} 7.4$ always show better reproducibility than the MTFE or GCE.

Differential pulse voltammograms with the DNA-GCE for different concentrations of metronidazole are shown for $\mathrm{pH} 4.5$ for 2 min preconcentration with stirring in Figure $4 \mathrm{a}$ and without preconcentration in Figure $4 \mathrm{~b}$. At $\mathrm{pH} 4.5$ with 2 min preconcentration there is good linearity, good sensitivity, and the limit of detection is $1.0 \mu \mathrm{M}$. Without preconcentration the sensitivity is not so good and the limit of detection is three times higher at $3.72 \mu \mathrm{M}$. The voltammograms for the reduction of metronidazole at $\mathrm{pH} 4.5$ showed the second reduction peak near $-0.85 \mathrm{~V}$, corresponding to the two electron step for reduction to the amine. When the DNAGCE is used at $\mathrm{pH} 7.4$ without preconcentration the results were better than at $\mathrm{pH} 4.5$ and the sensitivity and the limit of detection is

Table 2. Calibration plot data obtained at DNA-GCE, MTFE and GCE.

\begin{tabular}{llll}
\hline Electrode & Preconcentration & Linear range $[\mu M]$ & \\
\hline \multirow{2}{*}{ DNA-GCE } & $0 \mathrm{~min}$ & $4.76-54.3$ & $\mathrm{pH} 4.5$ \\
& $2 \mathrm{~min}$ & $1.0-54.3$ & $I_{\mathrm{p}}[\mu \mathrm{A}]=0.0586 C[\mu \mathrm{M}]-0.139(r=0.998, n=5)$ \\
$\mathrm{GCE}$ & & $1.96-54.3$ & $I_{\mathrm{p}}[\mu \mathrm{A}]=0.123 C[\mu \mathrm{M}]+0.00399(r=0.999, n=8)$ \\
MTFE & & $I_{\mathrm{p}}[\mu \mathrm{A}]=0.0477 C[\mu \mathrm{M}]-0.0591(r=0.999, n=7)$ \\
& & & $I_{\mathrm{p}}[\mu \mathrm{A}]=0.0934 C[\mu \mathrm{M}]-0.273(r=0.999, n=6)$ \\
DNA-GCE & $0 \mathrm{~min}$ & $1.0-54.3$ & $\mathrm{pH} 7.4$ \\
MTFE & & $2.91-54.3$ & $I_{\mathrm{p}}[\mu \mathrm{A}]=0.0806 C[\mu \mathrm{M}]-0.00046(r=0.999, n=9)$ \\
\hline
\end{tabular}
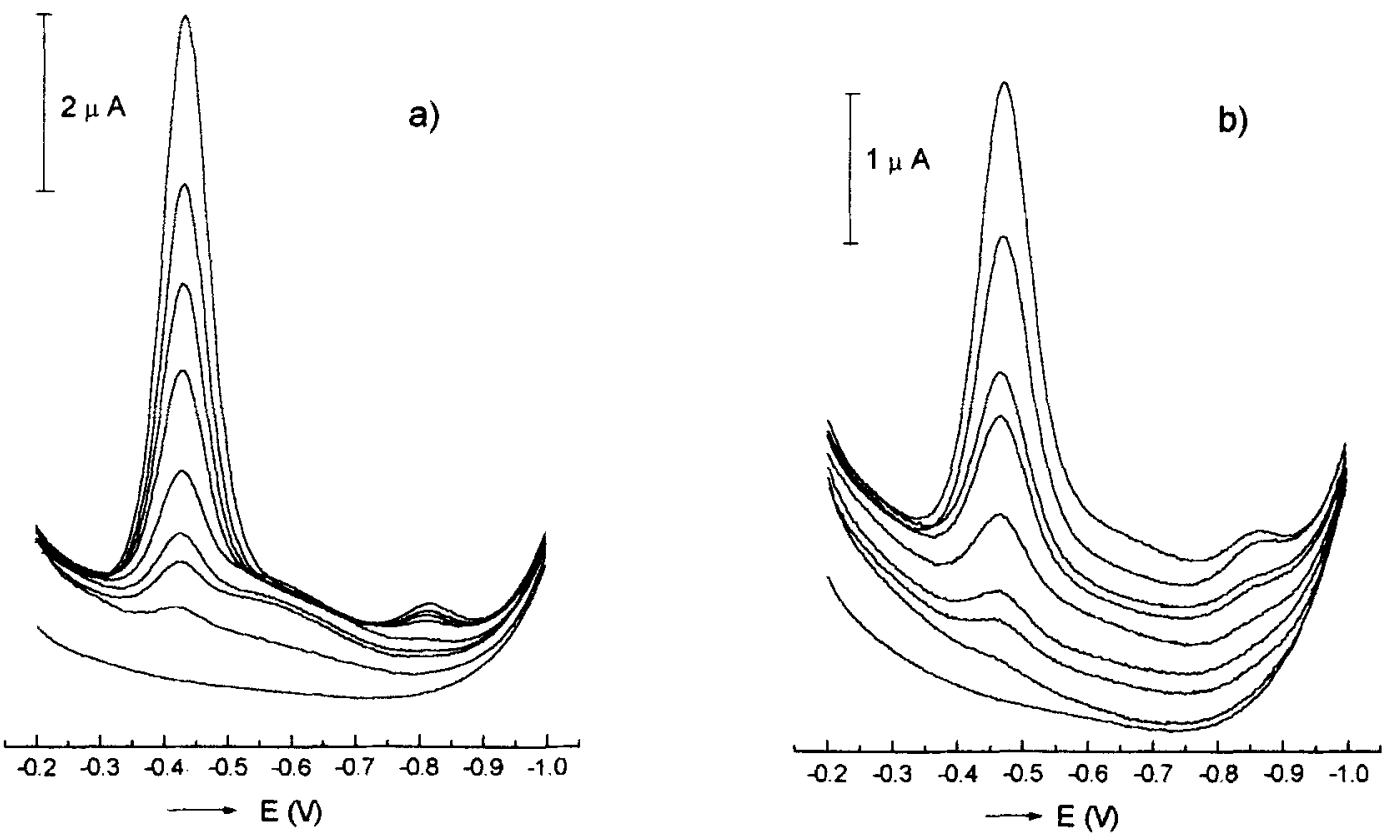

Fig. 4. Differential pulse (DP) voltammograms in $\mathrm{pH} 4.5$ citric acid/phosphate buffer: a) DNA-GCE, deposition time 2 min at $0.0 \mathrm{~V}$ with stirring; b) DNA-GCE and no preconcentration. DP conditions: pulse amplitude $50 \mathrm{mV}$, pulse width $70 \mathrm{~ms}$, pulse interval $0.4 \mathrm{~s}$ and scan rate $5 \mathrm{mV} \mathrm{s}^{-1}$. [MTZ] $=0.0 ; 1.0 ; 2.9 ; 4.8 ; 9.1$; $18.2 ; 27.2 ; 36.3 ; 54.3 \mu \mathrm{M}$. 

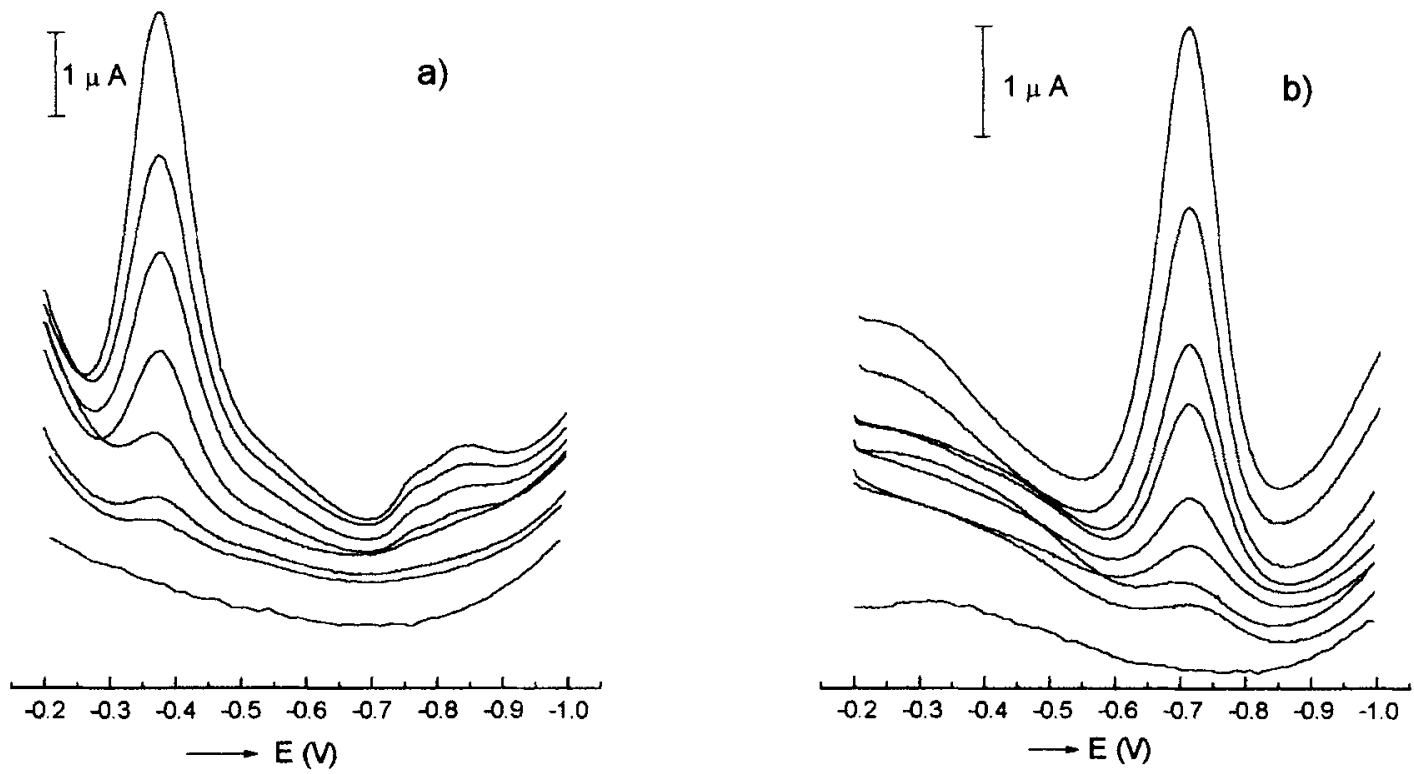

Fig. 5. Differential pulse (DP) voltammograms in citric acid/phosphate buffer at the MTFE: a) in pH 4.5; b) in pH 7.4. DP conditions: pulse amplitude $50 \mathrm{mV}$, pulse width $70 \mathrm{~ms}$, pulse interval $0.4 \mathrm{~s}$ and scan rate $5 \mathrm{mV} \mathrm{s}^{-1}$. [MTZ] $=0.0 ; 1.9 ; 2.9 ; 4.8 ; 9.1 ; 18.2 ; 27.2 ; 36.3 ; 54.3 \mu \mathrm{M}$.

$1.1 \mu \mathrm{M}$. For $\mathrm{pH} 7.4$ the use of preconcentration did not improve when compared to $\mathrm{pH} 4.5$.

Differential pulse voltammograms with the MTFE for different concentrations of metronidazole are shown for $\mathrm{pH} 4.5$ in Figure 5a and for $\mathrm{pH} 7.4$ in Figure $5 \mathrm{~b}$. The voltammograms for the reduction of metronidazole at $\mathrm{pH} 4.5$ also showed a second reduction peak near $-0.85 \mathrm{~V}$, corresponding to the two electron step for reduction to the amine. There is good linearity, but it is not possible to preconcentrate the metronidazole on the mercury film. The values for the currents measured were not significantly different but for $\mathrm{pH} 4.5$ the detection limit is $2.3 \mu \mathrm{M}$ and for $\mathrm{pH} 7.4$ the detection limit is $2.4 \mu \mathrm{M}$.

Similar experiments were performed with the bare GCE, and in Figure 6 are shown the differential pulse voltammograms for different concentrations of metronidazole without any preconcentration. For $\mathrm{pH} 4.5$ the detection limit is $1.2 \mu \mathrm{M}$. At $\mathrm{pH} 7.4$ bigger

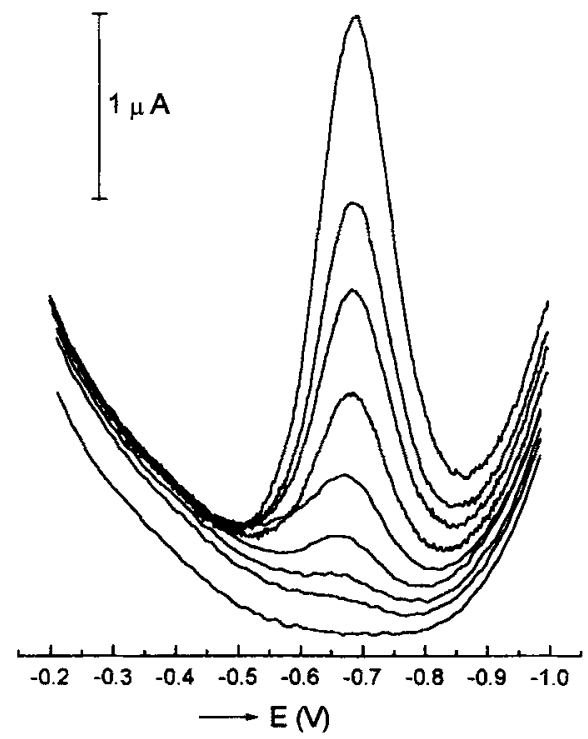

Fig. 6. Differential pulse (DP) voltammograms in $\mathrm{pH} 4.5$ in citric acid/ phosphate buffer at a bare GCE, $[\mathrm{MTZ}]=0.0 ; 1.0 ; 2.9 ; 4.8 ; 9.1 ; 18.2 ; 27.2$; $36.3 ; 54.3 \mu \mathrm{M}$. DP conditions: pulse amplitude $50 \mathrm{mV}$, pulse width $70 \mathrm{~ms}$, pulse interval $0.4 \mathrm{~s}$ and scan rate $5 \mathrm{mV} \mathrm{s}^{-1}$. currents for the reduction of metronidazole were observed; however, the linearity was not good and the linear range is only 4.8 to $36.3 \mu \mathrm{M}$. The detection limit is $3.6 \mu \mathrm{M}$.

\section{Conclusions}

All three electrodes show a similar trend in the reduction mechanism of metronidazole, being dependent on $\mathrm{pH}$ in the acid and neutral region and independent in alkaline media, although there was a shift in the peak potentials to more negative values when a bare glassy carbon electrode was used. At $\mathrm{pH} 4.5$ with the DNA-biosensor and the MTFE a second reduction peak was observed for the subsequent reduction to the amine.

In comparing the electroanalytical performance of the three electrodes: DNA-modified glassy carbon electrode, mercury thin film electrode and glassy carbon electrode, the DNA-modified glassy carbon electrode offered a lower detection limit of $1.0 \mu \mathrm{M}$ due to the higher currents obtained for the reduction of metronidazole and the possibility of preconcentration on the electrode surface. It is not possible to preconcentrate the analyte using either the mercury thin film electrode or a bare glassy carbon This is clearly an advantage of the DNA-modified electrode.

\section{Acknowledgement}

We thank CNPq (Brazil) for a fellowship to M.A. La-Scalea.

\section{References}

[1] D.I. Edwards, J. Antimicrob. Chemothr. 1993, 31, 2.

[2] D.I. Edwards, Comprehensive Medicinal Chemistry, Vol. 2, DNA Binding and Nicking Agents, in 5th ed (Ed: C. Hansch) Pergarnon Press, Oxford, 1990.

[3] Y.W. Chien, S.S. Mizuba, J. Med. Chem. 1978, 21, 374

[4] A.Z.A. Zuhri, S.I. Al-Khalil, M.S. Suleiman, Anal. Lett. 1986, 19, 453.

[5] Z. Wang, H. Zhou, S. Zhou, Talanta 1993, 40, 1073.

[6] P.J. Declerck, C.J. De Ranter, J. Chem. Soc., Faraday Trans 1. 1987, 83, 257.

[7] J.H. Tocher, D.I. Edwards, Biochem. Pharmac, 1994, 48, 1098. 
[8] D. Dumanovic, J. Volke, V. Vajgand, J. Pharm. Pharmac. 1966, 18, 507.

[9] D. Dumanovic, J. Ciric, Talanta 1973, 20, 525.

[10] D. Dumanovic, J. Jovanovic, D. Suznjevic, M. Erceg, P. Zuman, Electroanalysis 1992, 4,871.

[11] J.M.L. Fonseca, M.C.G. Rivera, J.C.G. Monteagudo, Anal. Lett 1973, 26, 109.

[12] S.C. Leach, R.D. Weaver, K. Kinoshita, W. Lee, J. Electroanal. Chem. 1981, $129,213$.
[13] P. Zuman, Z. Fijalek, D. Dumanovic, D. Suznjevic, Electroanalysis 1992, 4 783.

[14] C. Karakis, P. Zuman, J. Electroanal. Chem. 1995, 396, 499.

[15] A.M. Oliveira Brett, S.H.P. Serrano, T.A. Macedo, D. Raimundo, M.H Marques, M.A. La-Scalea, Electroanalysis 1996, 7, 992.

[16] E. Palecek, F. Jelen, C.T. Teijeiro, Anal. Chim. Acta 1993, 273, 175.

[17] C.T. Teijeiro, K. Nejedly, E. Palecek, J. Biomolec. Struct. Dynam. 1993, II, 313.

\section{Encyclopedia of Applied Physics}

\author{
Edited by G. L. Trigg
}

\section{An Indispensable Reference Library}

Subscription price per volume: DM 398.00.

Single volume price: DM 450.00 .

The Encyclopedia of Applied Physics comprises of 23 hardcover volumes arranged alphabetically.

'... Collaboration between universities and industry, with the aim of increasing competitiveness, is heavily emphasized by the funding agencies, and so applied physics assumes ever-increasing importance. Thus the work under review here, the Encyclopedia of Applied Physics comes at a highly appropriate time..

The encyclopedia is superb for browsing, exactly right for a researcher interested in a field in which he or she is not expert. The presentation, including diagrams and typography, is excellent..

In any case, this encyclopedia should be in the library of any institution where physics is studied."

Journal of Applied Physics

For an alphabetical list of contributions, visit our Physics Web Site at: http://www.vch.group.de/physics/books/eap_c.html

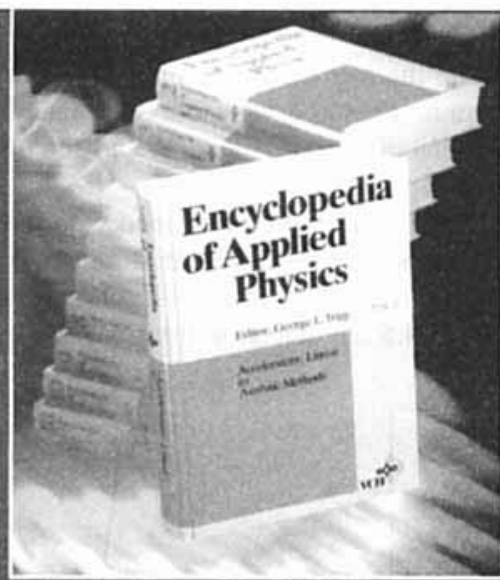

VCH,P.O. Box 101161 . D-69451 Weinheim Fax: $+49(0) 6201-606184$

John Wiley \& Sons, Inc.. 605 Third Avenue. New York, NY 10158-0012, Fax: +001 212 850-6088 John Wiley \& Sons, Ltd., Baffins Lane, Chichester. West Sussex, PO 19 1UD, England. Fax: $+44(0)$ 1243-775878 